\title{
Small-scale stress fluctuations in borehole breakouts and their implication in identifying potential active faults around the seismogenic megasplay fault, Nankai Trough, SW Japan
}

Yasuhiro Yamada ${ }^{1,2^{*}}$ and Jun Shibanuma ${ }^{1}$

\begin{abstract}
Borehole breakouts are enlargements and elongation of a borehole in a particular direction, caused by failure of the borehole wall rock due to concentration of stresses around the borehole, and thus, have been widely used to determine the in situ stress orientation. We used electrical borehole wall images obtained during offshore scientific drilling (IODP) that penetrated through a seismogenic megasplay fault in the Nankai Trough, off SW Japan, and extracted a number of borehole breakouts. Most of the breakouts show directions that can be explained by the regional convergence, but some are obviously rotated by faults and fractures in the megasplay fault zone and in its hanging wall. Stress magnitudes estimated from the width of the breakouts also show some decrease in the horizontal stresses, suggesting that slip along the faults and fractures release shear stress affecting these surfaces. Since such surfaces may have the capability to reactivate where the stresses affecting the surface are geometrically appropriate, the method presented in this paper may contribute to identifying active fault surfaces. This knowledge allows us to identify which surfaces need to be examined in detail to assess their potential for future activity.
\end{abstract}

Keywords: Borehole breakout; Stress rotation; Active fault identification; Nankai Trough; IODP

\section{Findings}

Introduction

Underground stresses are primarily controlled by combinations of three kinds of stresses: overburden stress, overburden-related confining stress, and tectonic stress. We can precisely determine the overburden stress at a particular depth by measuring the density of the sedimentary sequence (Jaeger and Cook 1979). Overburdenrelated confining stress is induced by the elastic effect of rock, and the horizontal compressive stress can be estimated by the Poisson's ratio of the rock and the overburden stress at that depth (Jaeger and Cook 1979). Tectonic stresses, however, show significant variations depending on the measurement location relative to the

\footnotetext{
* Correspondence: yyamada@jamstec.go.jp
'Department of Earth Resources Engineering, Graduate School of

* Correspondence: yyamada@jamstec.go.jp
'Department of Earth Resources Engineering, Graduate School of

Engineering, Kyoto University, Katsura, Kyoto 615-8540, Japan

${ }^{2}$ Research and Development Center for Ocean Drilling Science (ODS), Japan

Agency for Marine-Earth Science and Technology (JAMSTEC), 3173-25 Showa, Kanazawa, Yokohama 236-0001, Japan
}

regional tectonic environment and cannot be simply estimated. This is why in situ measurements are required to recognize underground stresses.

There are several techniques of in situ stress measurements, depending on the situation of the measurement point. The easiest and most widely used technique is the use of borehole wall failures (see Zoback 2007), such as borehole breakouts (BOs) and drilling-induced tensile fractures (DITFs). BOs and DITFs are both induced by stress field fluctuations where 'open space' exists underground, i.e., borehole drilling. Such fluctuation occurs because the borehole wall behaves as a free surface, and shear stress parallel to the wall does not propagate (Zoback 2007). As a result, stress concentrates on the borehole wall and fails if the stress condition fulfills an appropriate failure criterion of compressional or tensional environment. These phenomena of borehole failure are called BOs and DITFs, respectively. Significant BOs lead to drilling problems; thus, an appropriate drilling mud is used in oil/gas wells to prevent such failures. 
In scientific drilling, however, such costly mud is not used, and BOs occur frequently; nevertheless, these borehole failures have been positively used as important data to estimate underground stress fields.

In the past few decades, one or just a few measured values have been regarded as representative of an area of a few dozen square kilometers, assuming a simple homogeneous stress field. Such measured stress values are sometimes inconsistent with the regional stress field where discontinuity surfaces release the shear stress affecting these surfaces (Shamir and Zoback 1992; Barton and Zoback 1994; Zhang et al. 1994; Finkbeiner et al. 1997; Camac et al. 2006; Wu et al. 2007; Lin et al. 2010). Chang et al. (2010) conducted stress analysis at a subduction margin and reported a systematic change from a normal fault regime to a strike slip regime with depth. Most of these studies, however, used only the overall trend of stress orientations and gradual changes in stress magnitude. This paper reveals the detailed nature of the in situ stress state, detected by a stress analysis method using borehole wall failures, and shows frequent fluctuations in stress orientation and stress magnitude. The results can be applied to examine possible active faults around the megasplay fault zone at the Nankai subduction margin, off southwest Japan.

\section{Methods of stress analysis Underground stresses}

There are conditions that constrain the range of underground stress magnitude, defined by the principal stress magnitudes that can lead to rock failures. The term 'rock failure' includes both cases of creation of a new failure surface and slip (reactivation) along a preexisting failed surface. In the former case, the rock strength is provided by the sum of cohesion and sliding friction along a slip surface optimal to the local stress field. In the latter case, the sliding friction along the optimal surfaces is regarded as the strength, where no cohesion can be approximated along the surface. Thus, the strength is generally smaller than in the former case, if the geometrical relationship between the preexisting surfaces and the stress direction is not unfavorable. Based on this idea, Zoback (2007) assumed that the range of underground stress magnitude is determined by Coulomb frictional sliding on the optimally oriented surface. This Coulomb frictional sliding can be expressed as:

$$
\frac{\sigma_{1}}{\sigma_{3}}=\frac{S_{1}-P_{p}}{S_{3}-P_{p}}=\left(\sqrt{\mu^{2}+1}+\mu\right)^{2}
$$

where $\mu$ is the sliding frictional coefficient, $\sigma_{1}$ is the effective maximum compressive principal stress, $\sigma_{3}$ is the effective minimum compressive principal stress, $S_{1}$ is the maximum compressive principal stress, $S_{3}$ is the minimum compressive principal stress, and $P_{p}$ is the pore pressure.

\section{Stresses around a borehole}

The stress state around a borehole wall can be described with equations (2) to (4) using a cylindrical coordinate system whose central axis corresponds to the borehole axis (Zoback 2007). These equations assume that the rocks are isotropic elastic materials (Jaeger and Cook 1979).

$$
\begin{aligned}
\sigma_{\theta \theta}= & S_{H \max } \\
& +S_{h \min }-2\left(S_{H \max }-S_{h \min }\right) \cos 2 \theta-2 P o-\Delta P-\sigma^{\Delta T} \\
\sigma_{\mathrm{rr}}= & \Delta P \\
\sigma_{\mathrm{ZZ}}= & S_{v}-2 v\left(S_{H \max }-S_{h \min }\right) \cos 2 \theta-P_{0}-\sigma^{\Delta T}
\end{aligned}
$$

where $\sigma_{\theta \theta}$ is effective circumferential stress around the borehole, $\sigma_{\mathrm{rr}}$ is effective stress normal to the borehole axis, and $\sigma_{\mathrm{ZZ}}$ is effective stress in the vertical direction (along the borehole axis); $\theta$ is the angle from the $S_{H \max }$ direction; $P 0$ is pore pressure; $\Delta P$ is the difference between mud water pressure $P$ mud and pore pressure $P_{P}$; $\sigma^{\Delta T}$ is a stress caused by the difference of temperature between the mud and the formation; $v$ is the Poisson's ratio.

Defining the BO width as the angle from the center borehole axis 'Wbo,' stresses at that point rotated (Wbo/2) from the $S_{h \text { min }}$ direction may fulfill the condition of failure criteria. If the rock fails where $\sigma_{\theta \theta}$ is equal to the uniaxial compression strength (UCS), the relationship between the stresses can be derived from equation (2) as:

$$
S_{H \max }=\frac{\left(\mathrm{UCS}+2 P o+\Delta P+\sigma^{\Delta T}\right)-S_{h \min }(1+2 \cos 2 \theta)}{1-2 \cos 2 \theta}
$$

where the intermediate principal stress $\sigma_{2}$ can be neglected, the failure behavior may agree with the conventional Mohr-Coulomb failure criteria, but other cases need the modified Wiebols-Cook criteria, modified Lade criteria, or modified Drucker-Prager criteria (Colmenares and Zoback 2002). Chang et al. (2010) recommended using the modified Wiebols-Cook failure criteria (Zhou 1994) for sand and shale layers, as the effect of the intermediate principal stress cannot be neglected. This failure criterion, $J_{2}{ }^{1 / 2}$, is described in equation (6) with average stress $J_{1}$ and octahedral shear stress $\tau_{\text {oct }}$ :

$$
J_{2}{ }^{1 / 2}=\tau_{\text {oct }} \sqrt{3 / 2}=A+B J_{1}+C J_{1}{ }^{2}
$$

where $J_{1}$, toct, and $A, B$, and $C$ are

$$
J_{1}=\left(\sigma_{1}+\sigma_{2}+\sigma_{3}\right) / 3
$$




$$
\begin{aligned}
& \tau_{\mathrm{oct}}=\frac{\sqrt{\left(\sigma_{1}-\sigma_{2}\right)^{2}+\left(\sigma_{1}-\sigma_{3}\right)^{2}+\left(\sigma_{2}-\sigma_{3}\right)^{2}}}{3} \\
& A=\frac{\mathrm{UCS}}{\sqrt{3}}-\frac{\mathrm{UCS}}{3} B-\left(\frac{\mathrm{UCS}}{3}\right)^{2} C \\
& B=\frac{\sqrt{3}(q-1)}{q+2}-\frac{C}{3}\left[2 \mathrm{UCS}+(q+2) \sigma_{3}\right] \\
& C=\frac{\sqrt{27}}{2 C_{1}+(q-1) \sigma_{3}-\mathrm{UCS}}\left(\frac{C_{1}+(q-1) \sigma_{3}-\mathrm{UCS}}{2 C_{1}+(2 q+1) \sigma_{3}-\mathrm{UCS}}-\frac{q-1}{q+2}\right)
\end{aligned}
$$

where $C_{1}$ and $q$ are expressed in equations (12) and (13) with internal frictional coefficient $\mu_{i}$ :

$$
\begin{aligned}
& C_{1}=\left(1+0.6 \mu_{i}\right) \mathrm{UCS} \\
& q=\left[\left(\mu_{i}^{2}+1\right)^{1 / 2}+\mu_{i}\right]^{2}=\tan (\pi / 4+\varphi / 2)
\end{aligned}
$$

This modified Wiebols-Cook failure criteria looks complicated, but the only required parameters are UCS and $\mu_{i}$. These parameters can be measured and determined directly from rock tests on the core or samples obtained from appropriate outcrops. UCS can also be estimated using empirical equations between UCS and sonic velocity (e.g., Chang et al. 2006).

\section{Stress analysis at the Nankai accretionary wedge Data and methods}

To analyze the underground stresses introduced above, we used geophysical logging data and core measurement data, i.e., borehole image logging data (Figure 1), P-wave velocity from the sonic log, and the rock (core) strength data. All data were obtained during the first-stage drilling campaign (Kinoshita et al. 2009) of the Nankai Trough seismogenic zone experiment (NanTroSEIZE) of the Integrated Ocean Drilling Program (IODP), around the megasplay fault that may have been causing large earthquakes at the Nankai Trough (Moore et al. 2007; Park and Kodaira 2012). The strike and dip of this fault at drill site C0004B is approximately N50 to $65^{\circ} \mathrm{E}$ and 18 to $21^{\circ} \mathrm{NW}$, respectively, and the depth is 252 to $323 \mathrm{~m}$ below sea floor (mbsf; see Kimura et al. 2011 and Yamada et al. 2011, 2013 for detailed characteristics; also see Strasser et al. 2009 for its activity).

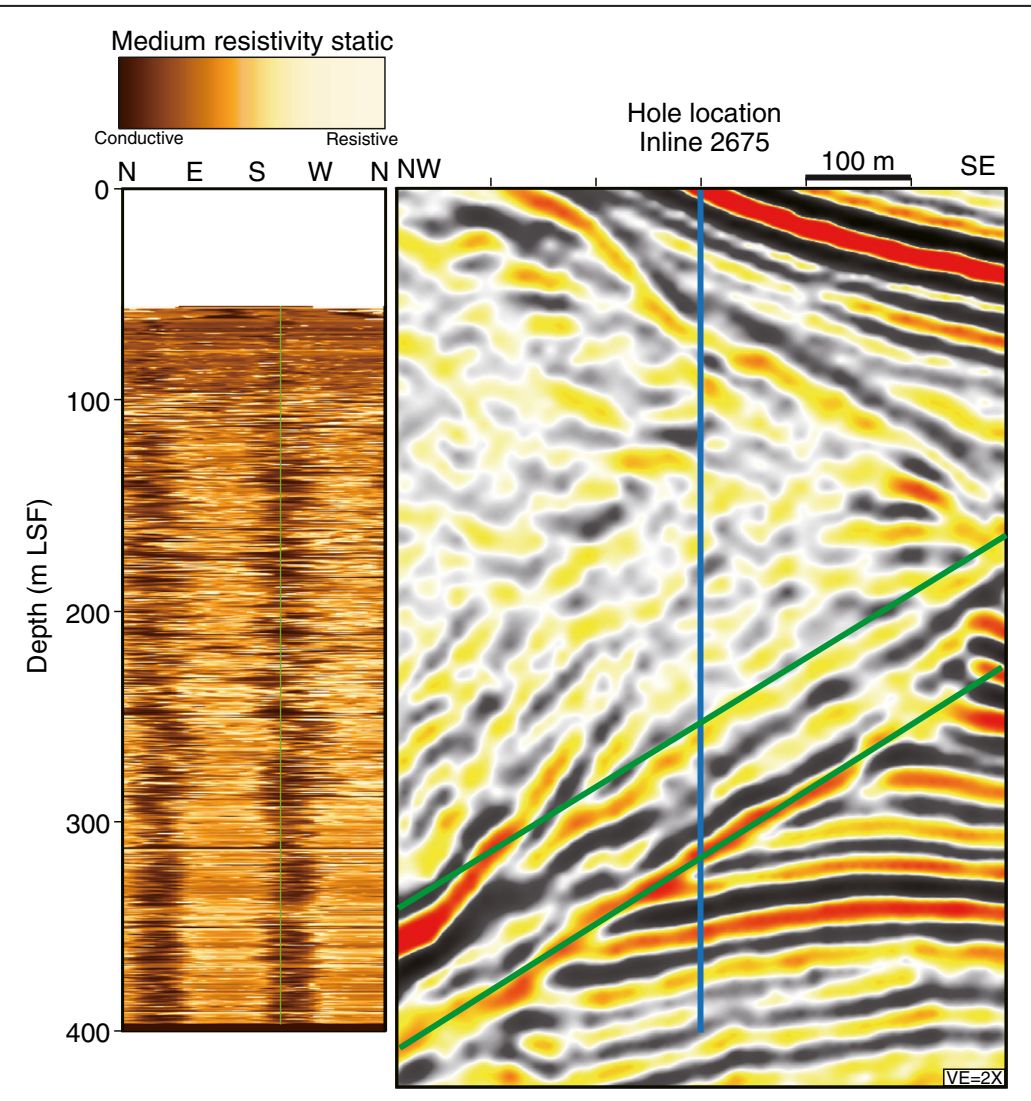

Figure 1 Borehole image data at C0004B (left) and the seismic profile through the well (right). The vertical scales of these figures are the same. The shallowest part of the image was not obtained during the operation; see Kinoshita et al. (2009) for details. The two green lines on the profile roughly correspond to the megasplay fault zone. 
We used the logging-while-drilling (LWD) resistivity logs as the borehole images and identified distinctive BOs in the images at site C0004B (Figures 1 and 2). DITFs were not observed, except for a few examples in the uppermost part of the image (56 to $61 \mathrm{mbsf}$ ) (Kinoshita et al. 2009). We measured the width and orientation of the $\mathrm{BO}$ depths of every 10 to $20 \mathrm{~cm}$ (Figure 2); then, the $\mathrm{BO}$ orientation was averaged over every meter.

In order to assume UCS from the sonic log using an empirical equation (e.g., Chang et al. 2006), we need rock mechanical data. Chang et al. (2010) reported several rock mechanical property datasets from this study area, consisting of three different sedimentary sequences: faulted trench deposits, highly deformed accretionary complexes, and weakly deformed fore-arc basin sediments. We chose two of these datasets obtained from similar geologic horizons (accretionary complex) at C0001 and C0002 (Table 1). Among five empirical equations proposed by Chang et al. (2006), equations A and $B$ seem to fit well with the two rock mechanical datasets (Figure 3). Considering the range (1,500 to $2,200 \mathrm{~m} / \mathrm{s})$ of the P-wave velocity at C0004B, the UCS estimate obtained using equation $\mathrm{A}$ is almost the same as that obtained using equation $\mathrm{B}$ and is far better than estimates from other equations. We therefore used only equation $\mathrm{A}$, and this resulted in the estimation of a single value of

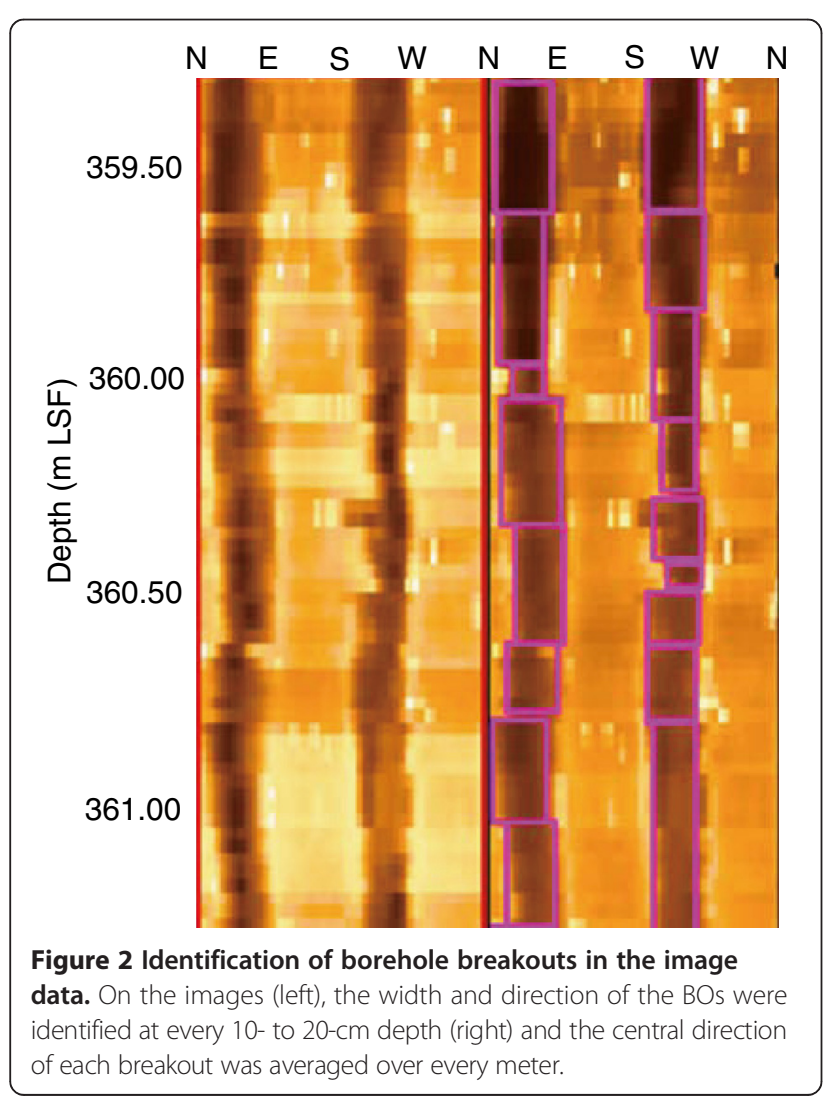

Table 1 Rock mechanical data used in this study

\begin{tabular}{llllll}
\hline Borehole & $\begin{array}{l}\text { Depth } \\
\text { (mbsf) }\end{array}$ & $\begin{array}{l}\text { UCS } \\
\text { (MPa) }\end{array}$ & $\begin{array}{l}\text { Internal } \\
\text { friction co. }\end{array}$ & $\begin{array}{l}\text { Poisson's } \\
\text { ratio }\end{array}$ & $\mathbf{V p ~ ( m / s )}$ \\
\hline C0001 & 334 & 3.2 & 0.53 & 0.34 & 1,843 \\
C0002 & 1,021 & 4.12 & 0.28 & 0.31 & 1,929 \\
\hline
\end{tabular}

Rock mechanical data used in this study, from Chang et al. (2010). These data were obtained with core samples from the accretionary complex.

UCS for every depth, using the corresponding P-wave velocity data. The internal friction coefficient was determined based on the rock mechanical data (Table 1) to be $0.41 . S_{V}$, the overburden pressure, was calculated from core density data reported by Kinoshita et al. (2009). We then followed the method proposed by Chang et al. (2010) to estimate the magnitudes of $S_{H \max }$ and $S_{\text {hmin }}$.

\section{Results and discussions}

This study found frequent stress rotations and localized negative anomalies in stress magnitude at the megasplay fault zone and its hangingwall. The following sections describe and discuss these findings.

Stress orientations The plot of the $\mathrm{BO}$ orientations with depth (Figure 4) shows that the two BOs at the same depth are roughly $180^{\circ}$ apart even where the BOs fluctuate. This means that the fluctuations of the $\mathrm{BO}$ direction are produced by systematic rotations of the BOs. The degree of rotation is generally $20^{\circ}$ from the average orientation, except for a few anomalous rotations of up to $30^{\circ}$ in the megasplay fault zone and its hangingwall (Figure 4).

As briefly introduced earlier, such rotations of stress orientations have been observed at some discontinuity

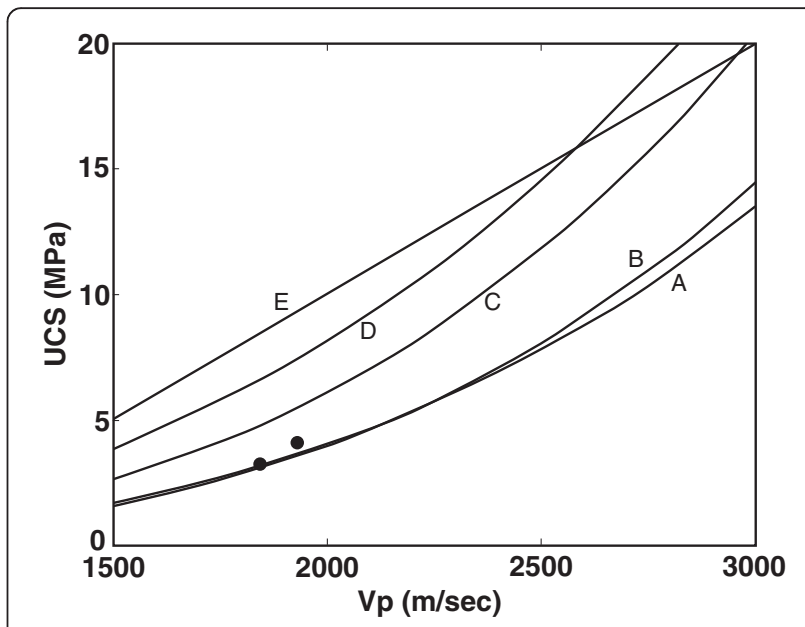

Figure 3 Empirical relation between UCS and Vp. Empirical relation between UCS and Vp (Chang et al. 2006) and core data used in this study (two dots: see Table 1). The range of $V p$ at C0004B is 1,500 to $2,200 \mathrm{~m} / \mathrm{s}$; thus, we used relation $A$. 


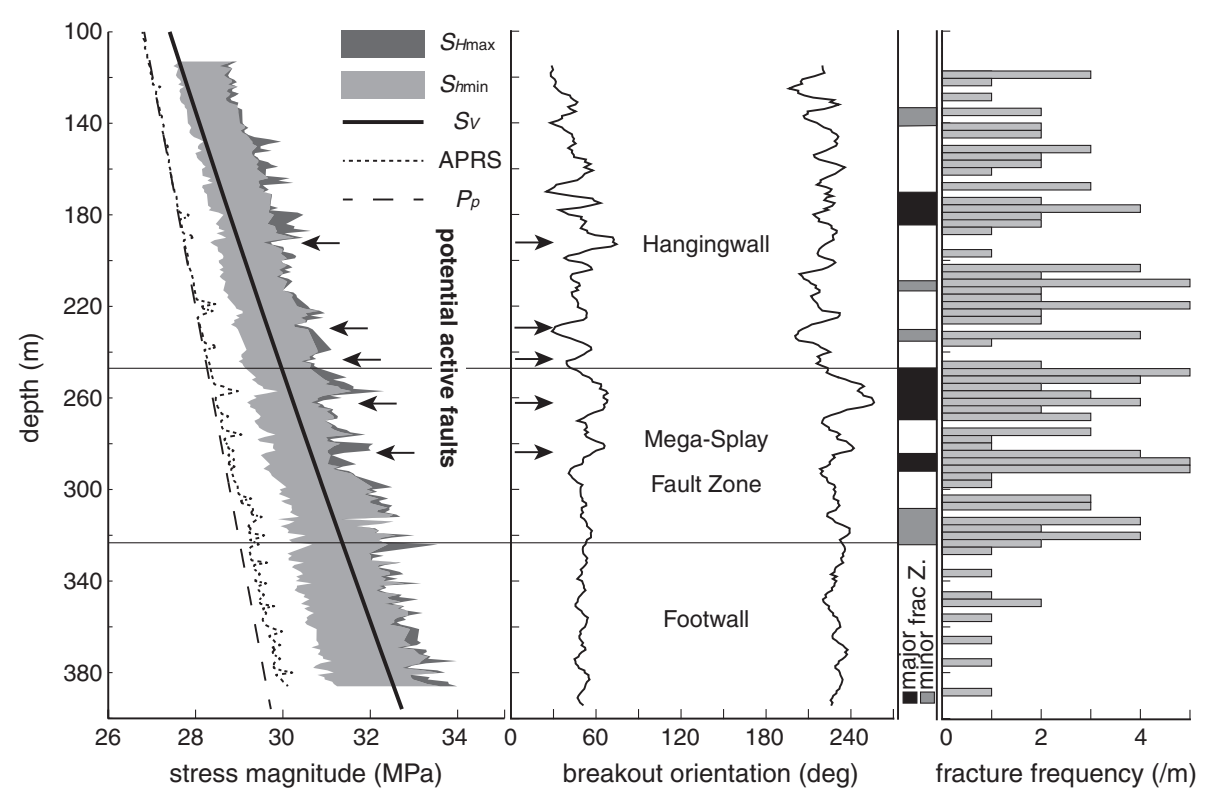

Figure 4 Stress magnitudes (left), breakout orientations (center), and fractures (right) identified at C0004B. The magnitude of $S_{V}$ may be smaller than that of $S_{H \max }$ but within the possible range of $S_{h m i n}$ suggesting that the stress around this borehole would be in a reverse fault or strike-slip fault regime. The plot of breakout orientations with depth, measured from the north, shows that the two breakouts at the same depth are roughly $180^{\circ}$ apart even where the direction of the breakouts fluctuates, suggesting that the fluctuations of breakout orientation are produced by systematic rotations. The heavily fractured zones with a high fracture frequency (Yamada et al. 2011) are within the megasplay fault zone and its hanging wall and generally correspond to the intervals of anomalous rotations of the breakouts and the decreases in stress magnitude. The arrows indicate possible active faults suggested by rotated and decreased stresses. APRS is the average annular pressure.

surfaces, probably from the release of shear stress affecting these surfaces (Shamir and Zoback 1992; Barton and Zoback 1994; Zhang et al. 1994; Finkbeiner et al. 1997; Camac et al. 2006; Wu et al. 2007; Lin et al. 2010). In order to examine this possibility, we looked at the fractured zones reported by Yamada et al. (2011) at C0004B. The fractured zones are defined by intense development of conductive fractures and recognized in the megasplay fault zone and its hangingwall, but there is no such zone in the footwall (Figure 4). By comparing the locations of the fractured zones and the stress rotations, we found that some of the fractured zones correspond to the depths of significant stress rotations (cf. 180 and 260 mbsf, Figure 4). These fractured zones may include faults that release the shear stresses affecting the surfaces. There is a slight difference in the overall breakout orientations between the hangingwall $\left(\mathrm{N} 44.8^{\circ} \mathrm{W}\right)$ and the footwall $\left(\mathrm{N} 49.8^{\circ} \mathrm{W}\right)$, which could be due to the megasplay fault zone behaving as a mechanical decoupling surface as a whole. The overall (average) $S_{H \max }$ orientations based on the $\mathrm{BO}$ direction agree with the overall shortening direction (Seno et al. 1993; Miyazaki and Heki 2001).

Stress magnitude Similar to the BO orientations, the stress magnitude shows frequent fluctuations (Figure 4), which may be due to several factors, as suggested by equation (5): UCS, pore pressure, pressure difference between borehole and rock pore, the temperature effect, and stress fields. The modified Wiebols-Cook failure criterion (see above) suggests that the internal friction should also control the failure. Other possible causes include 3D geometric problems, such as non-Andersonian stress states and inclined fault surfaces relative to the borehole.

In this study, UCS is approximated from P-wave velocity using the empirical relation (see above). The P-wave velocity from LWD geophysical logging data at C0004B shows a fluctuating pattern (Kinoshita et al. 2009), which may be induced by fractures and faults at the borehole wall. This is because of the data acquisition system of the measurement tool, which has a source and receiver for $\mathrm{P}$-waves, and the time required to transmit the wave delays if any discontinuity surface with aperture exists between these sensors (Kinoshita et al. 2009). This means that the approximated UCS will be reduced where mechanically decoupled surfaces exist.

Pore pressure along the megasplay fault surface has been a major target of investigations in the Nankai Trough, and reflection seismology data have been used for this purpose (e.g., Tsuji et al. 2008; Tobin and Saffer 2009). P-wave analysis suggests that overpressure could exist beneath the megasplay fault (Tsuru et al. 2005; 
Tsuji et al. 2006) but should not be significant in this region (Tsuji et al. 2011). These conclusions strongly depend on the spatial resolutions of seismic data, the theoretical limit of vertical resolution, $\lambda / 4$ (a quarter of the wavelength), being 5 to $7 \mathrm{~m}$ for near-surface sediments (Moore et al. 2007; Yamada et al. 2011); thus, there is still the possibility of elevated pore pressure along minor fault surfaces.

If we assume the pressure gradient to be hydrostatic at this site, the pressure difference between borehole and rock pore is generated by drilling mud pressure, because the drilling mud density was 1.024 (Kinoshita et al. 2009). A temporal increase in the mud pressure can be observed by the average annular pressure (APRS) profile in Figure 4, which has the effect of increasing $S_{H \max }$, but the magnitude of stress fluctuation is much more significant.

Site C0004B is located at 2,637 $\mathrm{m}$ of water depth and was drilled with a non-riser drilling system (Kinoshita et al. 2009), suggesting that the drilling mud may not have a significant temperature difference compared to the surrounding seawater at the ocean floor. The drilling interval at C0004B is only $400 \mathrm{~m}$ from the ocean floor; thus, the temperature around the borehole may also not be very different from the ocean floor temperature. These factors suggest that the temperature effect in equation (5) may be negligible.

Recent modeling studies (e.g., Yamada et al. 2014) suggest that stress fields in accretionary prisms may have temporal and spatial changes and are commonly inclined (i.e., non-Andersonian). This is primarily because of 'stick-slip' motion along faults that accumulates and releases elastic strain around the faults. The stress fluctuations due to such fault behavior can only be observed around active faults, and no fluctuation can be identified once fault activity has ceased. These modeling results suggest that the stress fluctuations found in this study may be associated with active faults.

The lithology at site C0004 has been reported to be mostly clay within the megasplay fault zone and in the hangingwall, based on core sample observations (Kinoshita et al. 2009). Although the core mechanical data (Table 1) show that the values of the internal friction coefficient have a variation of $30 \%$ from the average, there should not be any significant variation in the physical properties among such a small variety of rock types.

The dip of fault surfaces also has a significant impact on the breakout orientations (e.g., Shamir and Zoback 1992). This is because the orientation of the fault surface relative to the stresses defines the magnitude of release of shear stresses along the fault surface. The fracture surfaces identified in the borehole images at this site are scattered (Yamada et al. 2011); thus, this dip effect could explain the stress fluctuations.
As a result, our calculation shows that the magnitude of $S_{V}$ may be smaller than that of $S_{H \max }$, but within the possible range of $S_{h \mathrm{~min}}$, suggesting that the stress around this borehole would be in a reverse fault or strike-slip fault regime (Figure 4). Since $S_{V}$ seems to be close to the lower limit of the $S_{h \min }$ range, the stress at the shallow horizons (e.g., $120 \mathrm{mbsf}$ ) may have a higher possibility to be a reverse fault stress regime. If time-dependent failure of borehole wall due to drilling-induced overconsolidation of porous sediments (Moore et al. 2011) occurred, the magnitudes of horizontal stress that also favor thrust faulting would be even higher. These may agree with the strike-slip and thrusting motion of the megasplay fault suggested by the geometric features around the fault on seismic profiles and ocean floor topography (Tsuji et al. 2014).

\section{Implications for identifying active fault surfaces} Yamada et al. (2013) analyzed the detailed 3D geometry of the megasplay fault and argued that the megasplay fault may have been most active around the C0004B site. Since this part of the megasplay fault is thicker than the surrounding region (Yamada et al. 2013), the fault may have been generated during a long period of activity that contributed to form several possible active zones. The active parts of the fault zone, however, cannot be identified by such geometric investigations.

The analysis in this study identified systematic rotations of stress orientation and decreases in the stress magnitude, not only within the megasplay fault zone but also in its hangingwall. Since these stress fluctuations can be explained, at least partly, by stress release along mechanically decoupled surfaces, the depths that show such fluctuations may correspond to 'active faults' in terms of stresses. These active faults have not been completely healed by mineral precipitation but still have the capability to reactivate, where the stresses affecting on the surface are geometrically appropriate (e.g., Sibson 1995). Identification of discrete active fault surfaces among a number of possible discontinuity surfaces around an active fault zone is generally difficult, but this study showed that not only the megasplay fault zone but also several faults in its hangingwall may also currently have the potential to reactivate at site C0004 (see arrows in Figure 4). The spatial distribution of these potential active faults could also explain the anomalous heat flow distributions at the ocean floor (e.g., Yamano et al. 2014).

\section{Conclusions}

The stress state analyzed with the borehole breakouts identified in the borehole wall images obtained at site C0004B in the Nankai Trough, southwest Japan, shows that there are frequent but systematic stress fluctuations, 
i.e., rotations in stress orientation and decreases in stress magnitude, in the megasplay fault zone and its hangingwall. These fluctuations are probably induced by stress release along fault surfaces that can be regarded as active faults in terms of stresses and may still have the capability to reactivate. The approach presented in this paper allows us to identify which fault surfaces need to be examined in detail to understand the past development processes in order to assess their potential for future activity.

\section{Competing interests}

The authors declare that they have no competing interests.

\section{Authors' contributions}

YY conceived of the study, participated in IODP Expedition 314, and produced the manuscript. IS carried out the stress analysis with direction from YY. All authors read and approved the final manuscript.

\section{Authors' information}

YY earned a PhD in geology from Royal Holloway College, University of London, in 1999, and worked in the petroleum exploration industry before joining Kyoto University, where he was an associate professor from 2005 to 2014. YY moved to JAMSTEC in September 2014 to lead a research and development center for ocean drilling science (ODS). JS was a Master's degree student at Kyoto University.

\section{Acknowledgements}

We thank the editor M. Kinoshita and two anonymous reviewers for their comments and suggestions, which greatly helped to improve the manuscript. This research used data provided by the Integrated Ocean Drilling Program (IODP). Funding for this research was provided by Grants-in-Aid for Scientific Research (KAKENHI: 213101115 and 24540489) and for Scientific Research on Innovative Areas (21107002).

\section{Received: 12 March 2014 Accepted: 20 December 2014}

Published online: 06 February 2015

\section{References}

Barton CA, Zoback MD (1994) Stress perturbations associated with active faults penetrated by boreholes: possible evidence for near-complete stress drop and a new technique for stress magnitude measurements. J Geophys Res 99:9373-9390

Camac BA, Hunt S, Boult PJ (2006) Local rotations in borehole breakoutsobserved and modeled stress field rotations and their implications for the petroleum industry. Int J Geomech 6:399-410

Chang C, Zoback MD, Khaksar A (2006) Empirical relations between rock strength and physical properties in sedimentary rocks. J Petrol Sci Eng 51:223-237, doi; 10.1016/.jpetrol.2006.01.003

Chang C, McNeill LC, Moore JC, Lin W, Conin M, Yamada Y (2010) In situ stress state in the Nankai accretionary wedge estimated from borehole wall failures. Geochem Geophys Geosyst 11:Q0AD04, doi:10.1029/2010GC003261

Colmenares LB, Zoback MD (2002) A statistical evaluation of rock failure criteria constrained by polyaxial test data for five different rocks. Int J Rock Mech Mining Sci 39:695-729

Finkbeiner T, Barton CA, Zoback MD (1997) Relationships among in-situ stress, fractures and faults, and fluid flow: Monterey formation, Santa Maria Basin, California. AAPG Bull 81:1975-1999

Jaeger JC, Cook NGW (1979) Fundamentals of rock mechanics, 2nd edn. Chapman and Hall, New York

Kimura G, Moore GF, Strasser M, Screaton E, Curewitz D, Streiff C, Tobin H (2011) Spatial and temporal evolution of the megasplay fault in the Nankai Trough. Geochem Geophys Geosyst 12:Q0A008, doi:10.1029/2010GC003335

Kinoshita M, Tobin H, Ashi J, Kimura G, Lallement S, Screaton EJ, Curewitz D, Masago H, Moe KT, Expedition 314/315/316 Scientists (2009) Proc. Integrated Ocean Drilling Program 314/315/316. Integrated Ocean Drilling Program Management International, Inc, Washington, DC
Lin W, Yeh EC, Hung JH, Haimson B, Hirono T (2010) Localized rotation of principal stress around faults and fractures determined from borehole breakouts in hole B to the Taiwan Chelungpu-fault Drilling Project (TCDP). Tectonophysics 482(1-4):82-91

Miyazaki S, Heki K (2001) Crustal velocity field of southwest Japan: subduction and arc-arc collision. J Geophys Res 106:4305-4326, doi:10.1029/ 2000JB900312

Moore GF, Bangs NL, Taira A, Kuramoto S, Pangborn E, Tobin HJ (2007) Three-dimensional splay fault geometry and implications for tsunami generation. Science 318:1128-1131, doi:10.1126/science.1147195

Moore JC, Chang C, McNeill L, Thu MK, Yamada Y, Huftile G (2011) Growth of borehole breakouts with time after drilling: implications for state of stress, NanTroSEIZE transect, SW Japan. Geochem Geophys Geosyst 12:Q04D09, doi:10.1029/2010GC003417

Park J-O, Kodaira S (2012) Seismic reflection and bathymetric evidences for the Nankai earthquake rupture across a stable segment-boundary. Earth Planets Space 64:299-303, doi:10.5047/eps.2011.10.006

Seno T, Stein S, Gripp AE (1993) A model for the motion of the Philippine Sea plate consistent with NUVEL-1 and geological data. J Geophys Res 98:17941-17948, doi: 10.1029/93JB00782

Shamir G, Zoback MD (1992) Stress orientation profile to $3.5 \mathrm{~km}$ depth near the San Andreas Fault at Cajon Pass, California. J Geophys Res 97:5059-5080

Sibson RH (1995) Selective fault reactivation during basin inversion: potential for fluid redistribution through fault valve action. Geol Soc London Spec Publ 88:3-19

Strasser M, Moore GF, Kimura G, Kitamura Y, Kopf AJ, Lallemant S, Park JO, Screaton EJ, Su X, Underwood MB, Zhao X (2009) Origin and evolution of a splay fault in the Nankai accretionary wedge. Nat Geosci 2:648-652

Tobin HJ, Saffer DM (2009) Elevated fluid pressure and extreme mechanical weakness of a plate boundary thrust, Nankai Trough subduction zone. Geology 37:679-682, doi: 10.1130/G25752A

Tsuji T, Kimura G, Okamoto S, Kono F, Mochinaga H, Saeki T, Tokuyama H (2006) Modern and ancient seismogenic out-of-sequence thrusts in the Nankai accretionary prism: comparison of laboratory-derived physical properties and seismic reflection data. Geophys Res Let 33:L18309, doi:10.1029/ 2006GL027025

Tsuji T, Tokuyama H, Costa-Pisani P, Moore G (2008) Effective stress and pore pressure in the Nankai accretionary prism off the Muroto Peninsula, southwestern Japan. J Geophys Res 113:B11401, doi:10.1029/ 2007JB005002

Tsuji T, Dvorkin J, Mavko G, Nakata N, Matsuoka T, Nakanishi A, Kodaira S, Nishizawa O (2011) VP/NS ratio and shear-wave splitting in the Nankai Trough seismogenic zone: insights into effective stress, pore pressure, and sediment consolidation. Geophysics 76:WA71-WA82, doi:10.1190/1.3560018

Tsuji T, Ashi J, Ikeda Y (2014) Strike-slip motion of a mega-splay fault system in the Nankai oblique subduction zone. Earth Planets Space 66:120, doi:10.1186/1880-5981-66-120

Tsuru T, Miura S, Park J-O, Ito A, Fujie G, Kaneda Y, No T, Katayama T, Kasahara J (2005) Variation of physical properties beneath a fault observed by a two-ship seismic survey off southwest Japan. J Geophys Res 110:B05405, doi:10.1029/2004JB003036

Yamada Y, McNeill L, Moore JC, Nakamura Y (2011) Structural styles across the Nankai accretionary prism revealed from LWD borehole images and their correlation with seismic profile and core data: results from NanTroSEIZE stage 1 expeditions. Geochem Geophys Geosyst 12:Q0AD15, doi:10.1029/2010GC003365

Yamada Y, Masui R, Tsuji T (2013) Characteristics of a tsunamigenic megasplay fault in the Nankai Trough. Geophys Res Let 40:4594-4598, doi:10.1002/grl.50888

Yamada Y, Baba K, Miyakawa A, Matsuoka M (2014) Granular experiments of thrust wedges: insights relevant to methane hydrate exploration at the Nankai accretionary prism. Mar Petrol Geol 51:34-48, doi:10.1016/j.marpetgeo.2013.11.008

Yamano M, Kawada Y, Hamamoto H (2014) Heat flow survey in the vicinity of the branches of the megasplay fault in the Nankai accretionary prism. Earth Planets Space 66:126, doi:10.1186/1880-5981-66-126

Wu HY, Ma KF, Zoback M, Boness N, Ito H, Hung J-H, Hickman S (2007) Stress orientations of Taiwan Chelungpu-fault Drilling Project (TCDP) hole-A as observed from geophysical logs. Geophys Res Lett 34:L01303 
Zhang YZ, Dusseault MB, Yassir NA (1994) Effects of rock anisotropy and heterogeneity on stress distributions at selected sites in North America. Eng Geol 37:181-197

Zhou S (1994) A program to model the initial shape and extent of borehole breakout. Compt Rendus Geosci 20:1143-1160

Zoback MD (2007) Reservoir geomechanics. Cambridge Univ Press, Cambridge UK, p 464. ISBN 978-0521770699

Submit your manuscript to a SpringerOpen ${ }^{\odot}$ journal and benefit from:

- Convenient online submission

- Rigorous peer review

- Immediate publication on acceptance

- Open access: articles freely available online

- High visibility within the field

- Retaining the copyright to your article

Submit your next manuscript at $\gg$ springeropen.com 